\title{
Versatile peroxidase as a valuable tool for generating new biomolecules by homogeneous and heterogeneous cross-linking
}

\author{
Davinia Salvachúa $^{a}$, Alicia Prieto $^{a}$, Maija-Liisa Mattinen $^{b}$, Tarja Tamminen $^{\mathrm{b}}$, Tiina Liitiä $^{\mathrm{b}}$, \\ Martina Lille $^{\mathrm{b}}$, Stefan Willför ${ }^{\mathrm{c}}$, Angel T. Martínez ${ }^{\mathrm{a}}$, María Jesús Martínez ${ }^{\mathrm{a}, *}$, \\ Craig B. Faulds ${ }^{\mathrm{b}, 1}$ \\ a Centro de Investigaciones Biológicas, CSIC, Ramiro de Maeztu 9, E-28040 Madrid, Spain \\ b VTT Technical Research Centre of Finland, P.O. Box 1000, FI-02044 VTT, Finland

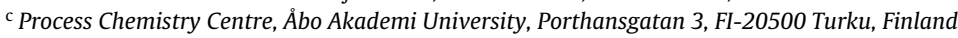

Keywords:

Enzymatic polymerization

Organic co-solvent

Lignan

Peptide

$\beta$-Casein

Feruloylated arabinoxylan

\begin{abstract}
A B S T R A C T
The modification and generation of new biomolecules intended to give higher molecular-mass species for biotechnological purposes, can be achieved by enzymatic cross-linking. The versatile peroxidase (VP) from Pleurotus eryngii is a high redox-potential enzyme with oxidative activity on a wide variety of substrates. In this study, VP was successfully used to catalyze the polymerization of low molecular mass compounds, such as lignans and peptides, as well as larger macromolecules, such as protein and complex polysaccharides. Different analytical, spectroscopic, and rheological techniques were used to determine structural changes and/or variations of the physicochemical properties of the reaction products. The lignans secoisolariciresinol and hydroxymatairesinol were condensed by VP forming up to 8 unit polymers in the presence of organic co-solvents and $\mathrm{Mn}^{2+}$. Moreover, 11 unit of the peptides YIGSR and VYV were homogeneously cross-linked. The heterogeneous cross-linking of one unit of the peptide YIGSR and several lignan units was also achieved. VP could also induce gelation of feruloylated arabinoxylan and the polymerization of $\beta$-casein. These results demonstrate the efficacy of VP to catalyze homo- and hetero-condensation reactions, and reveal its potential exploitation for polymerizing different types of compounds.
\end{abstract}

\section{Introduction}

Biotransformation is a useful way for modifying or producing novel structures and materials, which can then be exploited in a broad range of applications. The enzymatic polymerization and hetero-conjugation of various substrates is a method of primary interest to reach that goal. Biocatalysis is advantageous over chemical procedures, since: (i) it is an environmentally friendly alternative that uses milder and less contaminant reactions [1] and (ii) it can produce more specific cross-links, as many enzymes have high chemo-, regio-, and enantio selectivity [2]. The use of oxidoreductases, as radical-forming enzyme systems, to render homo or hetero-polymers of very diverse molecules is an attractive example of this, and the enzymatically synthesized polymers may exhibit

\footnotetext{
* Corresponding author. Tel.: +34 9183731 12; fax: +34 915360432.

E-mail address: mjmartinez@cib.csic.es (M.J. Martínez).

1 Current address: Biotechnologie des Champignons Filamenteux, INRAUniversité Aix Marseille, Polytech Marseille, 163 avenue de Luminy, 13288 Marseille Cedex 09, France.
}

new or improved properties in comparison with their respective precursors [3].

Versatile peroxidases (VP) are an interesting group of oxidoreductases (EC 1.11.1.16; described as a Reactive Black 5:hydrogen peroxide oxidoreductase) whose activity in these polymerization reactions has not been previously explored at the molecular level. These enzymes are secreted by fungi and included in the class II of the superfamily of plant-fungal-bacterial heme-peroxidases, together with manganese peroxidases $(\mathrm{MnP})$, lignin peroxidases (LiP), generic peroxidases (GP) as Coprinopsis cinerea (synonym Coprinus cinereus) peroxidase (CiP) [4]. To date, these enzymes and their encoding genes have been found and characterized only in white rot, wood-decaying Basidiomycota belonging to the class Agaricomycetes, as described in the comparative genomic research recently published by Floudas et al. [5]. VPs constitute an example of enzyme multifunctionality, combining the catalytic properties of MnP, LiP, and low redox-potential peroxidases. Therefore, VP displays a wide oxidative activity on substrates having different chemical structures and redox-potentials, including compounds that cannot be oxidized by low redox-potential peroxidases, such as fungal GP, horseradish peroxidase (HRP) and other plant peroxidases [6-9]. Recent research efforts of VPs have 
Version définitive du manuscrit publiée dans / Final version of the manuscript published in :

Enzyme and Microbial Technology (2013), Vol. 52, №.6-7, p. 303-311, DOl: 10.1016/j.enzmictec.2013.03.010 Journal homepage: http://www.elsevier.com/locate/emt

a)<smiles>COc1cc(C[C@@H](CO)[C@H](CO)Cc2ccc(O)c(OC)c2)ccc1O</smiles>

b)

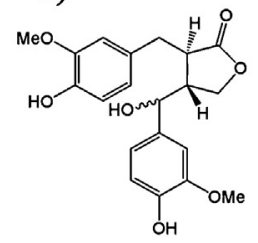

c)<smiles>COc1cc(C[C@@H]2C(=O)OC[C@@H]2Cc2ccc(O)c(OC)c2)ccc1O</smiles>

d)

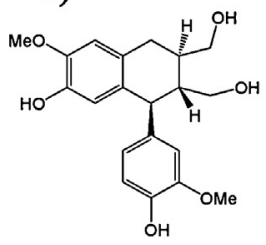

e)

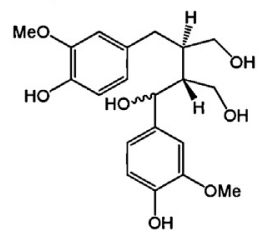

f)<smiles>CC(O)C1CCCCC1CO</smiles>

g)

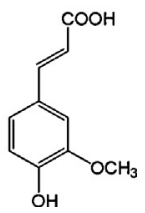

Fig. 1. Chemical structures of phenolic model compounds: (a) SECO, (b) HMR, (c) MR, (d) CYCLO, (e) 7-HSECO lignans, (f) tyrosine, and (g) trans-ferulic acid.

focused on the understanding of their reaction mechanisms and structure-function relationships [10,11], in the search of adequate systems for the expression of VP [12], and in enzyme improvement through directed evolution [13]. Nevertheless, the potential applications of VPs have not yet been fully exploited, in spite of being a very promising group of enzymes from a biotechnological point of view [14].

Different substrates previously used in enzymatic polymerization reactions [15-18], representing low-molecular mass, oligomeric, and polymeric substrates, were chosen to evaluate the polymerizing ability of VP. Lignans are diphenolic compounds found in the cell wall of higher plants, formed by $\beta-\beta$ coupling of two cinnamyl precursors [19], and their chemical structure depends especially on the plant species from which they are isolated. These compounds can appear in side-streams from industrial processing of lignocellulosic material, e.g. mechanical pulping and paper processing, and should be removed to avoid undesirable effects, such as interferences with process chemicals [20]. Polymerization of lignans into larger molecules is one way to eliminate these unwanted effects. Lignans may also serve as precursors for the enzymatic production of value-added polymers or materials with improved functional properties [21]. These synthetic reactions are challenging, since most of them may only be performed in the presence of organic solvents, jeopardizing the stability of the enzyme catalyst. On the other hand, the enzymatic polymerization of bioactive peptides, proteins as $\beta$-casein, or feruloylated arabinoxylans (FAX), which have well-known functional properties [19,22-24], could lead to tailored products with improved/modified organoleptic or functional properties such as reduced fat content, texture, solubility, mouth feel, better digestibility, emulsification, viscosity, gelling, or resistance to heat or proteolytic attack during enzyme digestion $[25,26]$.

Therefore, the aim of the present study was to determine if the VP from Pleurotus eryngii is able to catalyze the covalent homogeneous and/or heterogeneous cross-linking of selected small and large molecules, in the presence and absence of organic solvents, thus producing novel biocompounds. The extent of the condensation reactions was also evaluated.

\section{Materials and methods}

\subsection{Substrates}

The lignans used in this study (Fig. 1), namely secoisolariciresinol (SECO), hydroxymatairesinol (HMR), matairesinol (MR), cyclolariciresinol (CYCLO), and 7hydroxy-secoisolariciresinol (7-HSECO) were prepared as described earlier [27-29]. The bioactive peptides EPPGGSKVILF, RKRSRKE, VEPIPY, YIGSR, and VYV were obtained from Sigma (St. Louis, MO, USA). YST was bought from Biokemis (Saint Petersburg, Russia). GLY was obtained from Fluka (Buchs, Switzerland). The bovine $\beta$-casein protein ( $24 \mathrm{kDa}, 85 \%$ purity) was purchased from Sigma-Aldrich (Taufkirchen, Germany). FAX from maize bran, containing an alkali-extractable ferulic acid content of $6.2 \mathrm{mg} \mathrm{g}^{-1}$, was kindly given to CBF by Cambridge Biopolymers Ltd. (Cambridge, UK).

\subsection{Enzyme activity}

VP was isolated and purified from $P$. eryngii cultures as previously described [30]. Its $\mathrm{Mn}^{2+}$-oxidizing activity was determined spectrophotometrically at $238 \mathrm{~nm}$ through the formation of the $\mathrm{Mn}^{3+}$.tartrate complex $\left(\varepsilon_{238}=6500 \mathrm{M}^{-1} \mathrm{~cm}^{-1}\right)$ in a reaction mixture containing $0.1 \mathrm{mM} \mathrm{MnSO}_{4}\left(\mathrm{Mn}^{2+}\right)$ in $25 \mathrm{mM}$ sodium tartrate buffer ( $\mathrm{pH}$ 5.0), with the addition of $0.1 \mathrm{mM} \mathrm{H}_{2} \mathrm{O}_{2}$ to start the reaction. The effect of two organic solvents on VP activity was also checked through the evaluation of $\mathrm{Mn}^{2+}$-independent activities following the oxidation of $1 \mathrm{mM}$ 2,6-dimethoxyphenol (DMP) to dimeric coerulignone $\left(\varepsilon_{469}=55,000 \mathrm{M}^{-1} \mathrm{~cm}^{-1}\right)$ and $1 \mathrm{mM} \mathrm{2,2}$-azino-bis (3ethylbenzothiazoline-6-sulphonic acid)(ABTS) to $\operatorname{ABTS}^{+}\left(\varepsilon_{436}=29,300 \mathrm{M}^{-1} \mathrm{~cm}^{-1}\right)$ in $25 \mathrm{mM}$ sodium tartrate buffer ( $\mathrm{pH} 5.0$ ). Solutions containing from $0 \%$ to $50 \%(\mathrm{v} / \mathrm{v}$ ) of either ethanol or 1,2-propanediol in $25 \mathrm{mM}$ sodium tartrate buffer ( $\mathrm{pH} 5.0$ ), in the presence or absence of $0.1 \mathrm{mM} \mathrm{Mn}^{2+}$ and $0.1 \mathrm{mM} \mathrm{H}_{2} \mathrm{O}_{2}$, were prepared as solvents for the substrates. The VP stability during 24 h-reactions was also checked in $25 \mathrm{mM}$ sodium tartrate buffer ( $\mathrm{pH} 5.0$ ), 20\%, and 50\% ethanol (dissolved in the same buffer at equal final concentration), with and without $\mathrm{Mn}^{2+}$. The percentage of residual activity was calculated at $0,0.5,2$, and $24 \mathrm{~h}$ using $\mathrm{Mn}^{2+} \mathrm{H}_{2} \mathrm{O}_{2}$ as substrates and taking the initial activity in buffer as $100 \%$. Measurements were carried out in triplicate at room temperature. One unit of activity $(1 \mathrm{U})$ is defined as the amount of enzyme releasing $1 \mu \mathrm{mol}$ of product per minute under the defined reaction conditions.

\subsection{Substrate solutions}

The lignan SECO $(3 \mathrm{mM})$, all peptides $(3 \mathrm{mM}), \beta$-casein $\left(1 \mathrm{mg} \mathrm{mL}^{-1}\right)$, and FAX (30 $\mathrm{mg} \mathrm{mL}^{-1}$ ) were prepared in $25 \mathrm{mM}$ sodium tartrate buffer ( $\mathrm{pH} 5.0$ ). The remaining lignans were dissolved in $20 \%$ ethanol in the same buffer at a $3 \mathrm{mM}$ final concentration, except 7-HSECO, which was dissolved in 50\% ethanol buffer. All solutions were left standing for at least $30 \mathrm{~min}$ to be stabilized before commencing the enzymatic treatments.

\subsection{Cross-linking assays}

The enzyme reactions detailed below were initiated by addition of $0.1 \mathrm{mM} \mathrm{H}_{2} \mathrm{O}_{2}$, supplementing with a second dosage after $1 \mathrm{~h}$ of incubation and briefly agitated after each $\mathrm{H}_{2} \mathrm{O}_{2}$ supplementation. As an exception, the FAX assays were performed with a single dosage of $0.2 \mathrm{mM} \mathrm{H} \mathrm{H}_{2} \mathrm{O}_{2}$ at the beginning of the treatment. Unless otherwise stated, these treatments were performed in the presence of $\mathrm{Mn}^{2+}(0.1 \mathrm{mM})$, in duplicate, at room temperature. Negative controls consisted of reactions lacking VP or $\mathrm{H}_{2} \mathrm{O}_{2}$ incubated under the same conditions than the test reactions (with and without $\mathrm{Mn}^{2+}$ ).

\subsubsection{Homogeneous cross-linking of lignans and peptides}

The polymerization of different substrates was performed in $1.5 \mathrm{~mL}$ Eppendorf tubes with a $1.5 \mathrm{U} \mathrm{mL}^{-1} \mathrm{VP}$ in a final volume of $200 \mu \mathrm{L}$. Aliquots $(3 \mu \mathrm{L})$ of each reaction mixture were removed after 0.5 and $2 \mathrm{~h}$ of incubation for subsequent analysis by matrix-assisted laser desorption/ionization-time of flight-mass spectroscopy (MALDI-TOF MS). Lignan treatments were also performed during $24 \mathrm{~h}$, in the absence of $\mathrm{Mn}^{2+}$. To stop these reactions $0.05 \%(\mathrm{w} / \mathrm{v}) \mathrm{NaN}_{3}$ was added and samples from lignan treatments were lyophilized for further size exclusion chromatography (SEC) analysis. The effect on the polymerization efficiency of a lower enzymatic dose $\left(0.15 \mathrm{U} \mathrm{mL}^{-1}\right)$ and a higher $\mathrm{H}_{2} \mathrm{O}_{2}$ concentration $(0.5 \mathrm{mM})$, during $0.5,2$ and $24 \mathrm{~h}$, was studied and separately assayed using HMR lignan as substrate.

\subsubsection{Heterogeneous cross-linking of lignans with peptides}

Reactions containing equal volumes $(85 \mu \mathrm{L})$ of the $3 \mathrm{mM}$ solutions of the SECO or HMR lignans and of the tyrosine-containing peptides were mixed with $1.5 \mathrm{U} \mathrm{mL}^{-1}$ $\mathrm{VP}$, in a final volume of $200 \mu \mathrm{L}$. Aliquots $(3 \mu \mathrm{L})$ were withdrawn after 0.5 and $2 \mathrm{~h}$ reaction and analyzed by MALDI-TOF MS.

\subsubsection{Homogeneous cross-linking of $\beta$-casein}

Three VP doses $\left(0.015,0.15\right.$, and $\left.1.5 \mathrm{U} \mathrm{mL}^{-1}\right)$ were assayed in $1 \mathrm{~mL}$ reactions for $\beta$-casein polymerization, incubating separately for 2,6 , and $24 \mathrm{~h}$ with continuous stirring at $300 \mathrm{rpm}$. Aliquots $(30 \mu \mathrm{L})$ from each treatment were separated and immediately mixed with loading buffer $(10 \mu \mathrm{L})$, boiled for $10 \mathrm{~min}$ and analyzed by sodium dodecyl sulphate-polyacrylamide gel electrophoresis (SDS-PAGE). The remaining enzymatic reactions were stopped with $\mathrm{NaN}_{3}(0.05 \%, \mathrm{w} / \mathrm{v})$ and samples were lyophilized for further transmission electron microscopy (TEM) analysis.

\subsubsection{Homogeneous cross-linking of FAX}

The ability of VP to cross-link FAX, inducing gel formation, was investigated in reactions containing VP doses of $0.015,0.15,1.5 \mathrm{U} \mathrm{mL}^{-1}$ in a total volume of $1.5 \mathrm{~mL}$. 
Version définitive du manuscrit publiée dans / Final version of the manuscript published in :

Enzyme and Microbial Technology (2013), Vol. 52, №.6-7, p. 303-311, DOI: 10.1016/j.enzmictec.2013.03.010

Journal homepage: http://www.elsevier.com/locate/emt

Mixtures were briefly vortexed and $1.3 \mathrm{~mL}$ was immediately removed and placed on the rheometer plate. Rheological analysis started 3 min after $\mathrm{H}_{2} \mathrm{O}_{2}$ activation. For swelling experiments, reactions were prepared with the same enzyme doses, in $2 \mathrm{~mL}$ syringes (diameter $1.5 \mathrm{~cm}$ ), in a final volume of $1 \mathrm{~mL}$. Reactions were allowed to gel for $15 \mathrm{~h}$ before analyzing the swelling degree.

\subsection{MALDI-TOF MS analyses}

MALDI-TOF MS spectra of VP-treated lignans and peptides were recorded on a Bruker Autoflex II instrument equipped with a $\mathrm{N}_{2}$-laser $(337 \mathrm{~nm}, 100 \mu \mathrm{J})$ and previously calibrated with peptide and protein standard solutions from same distributor (Bremen, Germany). For the analyses, $3 \mu \mathrm{L}$ of the reaction solution were mixed 1:1 (v:v) with saturated $\alpha$-cyano-4-hydroxycinnamic acid matrix from Sigma-Aldrich (St. Louis, MO, USA) dissolved in $0.1 \%$ trifluoroacetic acid from Fluka (Buchs, Switzerland) containing $50 \%$ acetonitrile. $1 \mu \mathrm{L}$ of the sample-matrix solution was spotted onto the stainless steel target plate and allowed to dry at room temperature. Positive ion mass spectra were recorded in reflector mode $(\mathrm{m} / \mathrm{z}$ range $500-3500)$ and linear mode ( $m / z$ range 3500-10000). FlexAnalysis (version 2.4) was used for data analysis (Bruker, Bremen, Germany). Lignans were detected as their sodium adducts.

\subsection{SEC analyses}

Samples from lignan treatments were dissolved in $0.1 \mathrm{M} \mathrm{NaOH}$ and analyzed by high performance SEC eluting with the same solvent $\left(0.5 \mathrm{~mL} \mathrm{~min}^{-1}\right.$ flow rate) at $25^{\circ} \mathrm{C}$, in MCX 1000 and $100,000 \AA$ columns connected in tandem and coupled to a precolumn (all from PSS Mainz, Germany). The elution profiles were followed at $280 \mathrm{~nm}$ with a Waters UV detector. The molar mass distributions (MMD), and weight average molar masses $\left(M_{w}\right)$ were calculated against polystyrene sulphonate (Na-PSS) standards, using the Waters Empower 2 software.

\subsection{SDS-PAGE analysis}

SDS-PAGE was used to analyze the formation of $\beta$-casein polymers smaller than $250 \mathrm{kDa}$. Samples were loaded onto Criterion TGX Stain-Free ${ }^{\mathrm{TM}}$ precast gels (4-20\%) and visualized on the Criterion Stain Free ${ }^{\mathrm{TM}}$ Imager System. Precision Plus Protein $^{\mathrm{TM}}$ Standards (10-250 kDa) were used for molecular weight estimations. All instruments and reagents were purchased to Bio-Rad (Hercules, CA, USA).

\subsection{Microscopy analysis}

Lyophilized $\beta$-casein samples, subjected or not to a $24 \mathrm{~h}$ VP treatment, were dissolved in distilled water or $6 \mathrm{M}$ urea to observe non-enzymatic aggregates and enzymatic cross-links, respectively. Glow-discharged carbon-coated formvar grids were placed face-down over a droplet of sample. After $1 \mathrm{~min}$, the grid was removed, blotted briefly with filter paper and negatively stained with $2 \%$ uranyl acetate for $40 \mathrm{~s}$, blotted quickly and air-dried. Samples were observed by TEM in a JEOL 1230 instrument (Tokyo, Japan) operated at $100 \mathrm{kV}$.

\subsection{Rheological measurements and gel swelling analysis}

The gelation of the cross-linked FAX was monitored by using an AR-G2 rheometer (TA Instruments, Crawley, UK) in oscillatory mode at a constant temperature of $22^{\circ} \mathrm{C}$. A plate-plate geometry with a diameter of $40 \mathrm{~mm}$ and a gap of $1 \mathrm{~mm}$ was used for the measurements, with a solvent trap to prevent sample drying during analysis. Gel formation was followed during $4 \mathrm{~h}$, by monitoring the storage modulus $\left(G^{\prime}\right)$, the loss modulus $\left(G^{\prime \prime}\right)$ and the phase angle at a constant frequency of $0.1 \mathrm{~Hz}$ and a strain of $0.01 \%$.

To evaluate the gel swelling properties, cross-linked FAXs were allowed to swell in $10 \mathrm{~mL}$ of a $0.02 \%(\mathrm{w} / \mathrm{v}) \mathrm{NaN}_{3}$ solution. After $32 \mathrm{~h}$, samples were blotted, weighted, and subsequently added to new $\mathrm{NaN}_{3}$ solutions at room temperature. The equilibrium swelling was reached when the weight of the samples did not change more than $3 \%$. The swelling ratio $(q)$ is calculated according to the equation: $q=\left(W_{s}-W_{i}\right) / W_{i}$, where $W_{s}$ is the weight of the swollen gel at each measured time and $W_{i}$ is the weight of the gel before swelling.

\section{Results and discussion}

\subsection{Influence of organic co-solvents and $\mathrm{Mn}^{2+}$ on VP activity and stability}

The lignans included in the present study were selected for their different structures and the degree of solubility in aqueous solutions or organic co-solvents. Enzymes can be severely affected by the presence of organic solvents, which generally cause a sharp activity drop due to modification of the protein conformation [31]. For this reason, VP activity was first established in the presence of different concentrations of ethanol and 1,2-propanediol,

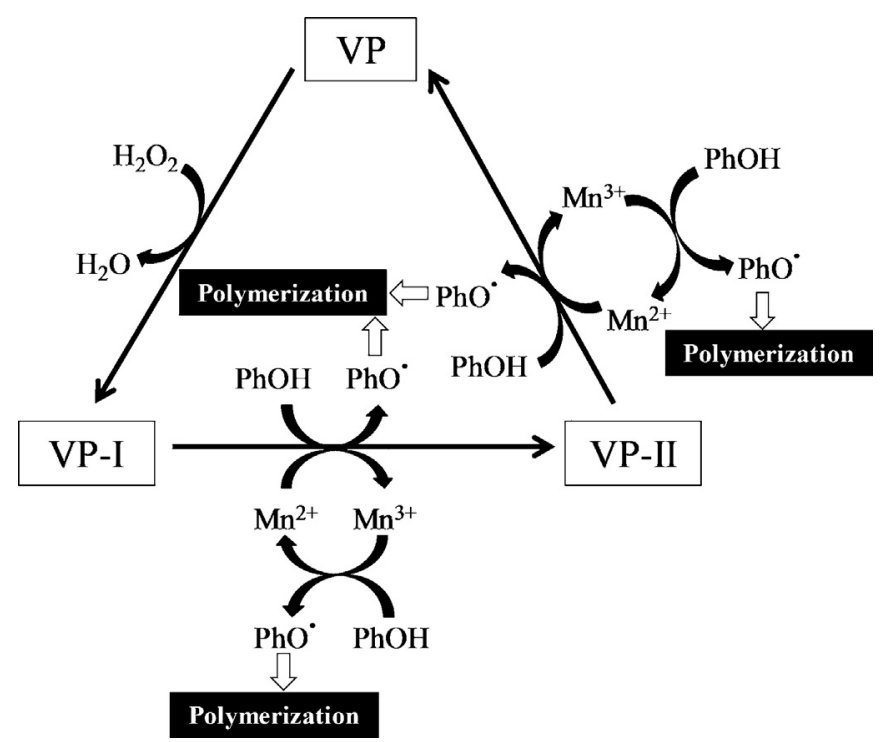

Fig. 2. Scheme of the versatile peroxidase (VP) catalytic cycle adapted from RuizDueñas et al. [10]. As shown, VP can oxidize, among others: (i) phenolic substrates $(\mathrm{PhOH})$, such as lignans and tyrosine, to the corresponding phenoxy radicals ( $\mathrm{PhO}$.) which are able to polymerize; and (ii) $\mathrm{Mn}^{2+}$ to $\mathrm{Mn}^{3+}$, the latter acting as a diffusible oxidizer of different compounds including phenols.

two solvents chosen for their ability to solubilize softwood and hardwood lignins and for being completely water-miscible. Initial activities in aqueous buffers were determined to be $15 \mathrm{U} \mathrm{mL}^{-1}$ for $\mathrm{Mn}^{2+}, 1 \mathrm{U} \mathrm{mL}^{-1}$ with ABTS, and $0.4 \mathrm{U} \mathrm{mL}^{-1}$ for DMP. VP-activity against ABTS and DMP increased in the presence of $\mathrm{Mn}^{2+}$, reaching $1.6 \mathrm{U} \mathrm{mL}^{-1}$ and $3.6 \mathrm{U} \mathrm{mL}^{-1}$, respectively. This enhanced activity on phenols and dyes in $\mathrm{Mn}^{2+}$-containing reactions has been previously reported [30], and it is related to the catalytic versatility of $\mathrm{VP}$, oxidizing them in both $\mathrm{Mn}^{2+}$-independent and $\mathrm{Mn}^{2+}$-mediated reactions (Fig. 2).

Fig. 3 shows the effect of the two solvents on $\mathrm{Mn}^{2+}$, DMP, and ABTS oxidation. As 1,2-propanediol concentration increased (Fig. 3a), a concurrent decrease in VP residual activity was observed. The decrease was significantly lower in reactions with $\mathrm{Mn}^{2+}$, especially at high solvent concentrations, although some activity was retained in all reactions even with $50 \%$ of this organic solvent. On the other hand, the effect of ethanol on VP activity (Fig. 3b) was diverse. With $\mathrm{Mn}^{2+}$ as the substrate, VP was quite stable in up to $40 \%$ ethanol, with only a $30 \%$ decrease in activity. The oxidation of DMP in the presence of $\mathrm{Mn}^{2+}$ appeared not to be affected by the use of ethanol concentrations $\leq 20 \%$. The activity of a B. adusta VP at low ethanol concentrations has also been described [32] although, according to our data, the VP from $P$. eryngii seems to be more resistant. However, a high activity loss was observed in DMP reactions without $\mathrm{Mn}^{2+}$ that could be explained by reduced accessibility of ethanol through the narrow Mn-oxidation channel, compared with the main heme access-channel where DMP is oxidized [33]. From the above results, and taking into account that most of the lignans used in this study are soluble at low ethanol concentrations (20\%), this solvent was selected for further enzyme stability assays. The enzyme in buffer, as well as in the presence or absence of $\mathrm{Mn}^{2+}$, retained the initial activity during the $24 \mathrm{~h}$ of incubation. With $20 \%$ ethanol in the absence of $\mathrm{Mn}^{2+}$, the residual activity was 84 and $43 \%$ at 0.5 and $24 \mathrm{~h}$, respectively, while in the presence of the ion was 87 and $82 \%$ (with 50\% ethanol the enzyme lost its activity quickly, retaining $3.4 \%$ and $2.1 \%$ activity after $0.5 \mathrm{~h}$ with and without $\mathrm{Mn}^{2+}$, respectively). It can thus be concluded that the presence of $\mathrm{Mn}^{2+}$ exerts a stimulating and stabilizing effect on the oxidation reactions and VP respectively. The former effect is due to $\mathrm{Mn}^{3+}$-mediated 
Version définitive du manuscrit publiée dans / Final version of the manuscript published in :

Enzyme and Microbial Technology (2013), Vol. 52, №.6-7, p. 303-311, DOl: 10.1016/j.enzmictec.2013.03.010 Journal homepage: http://www.elsevier.com/locate/emt

a)

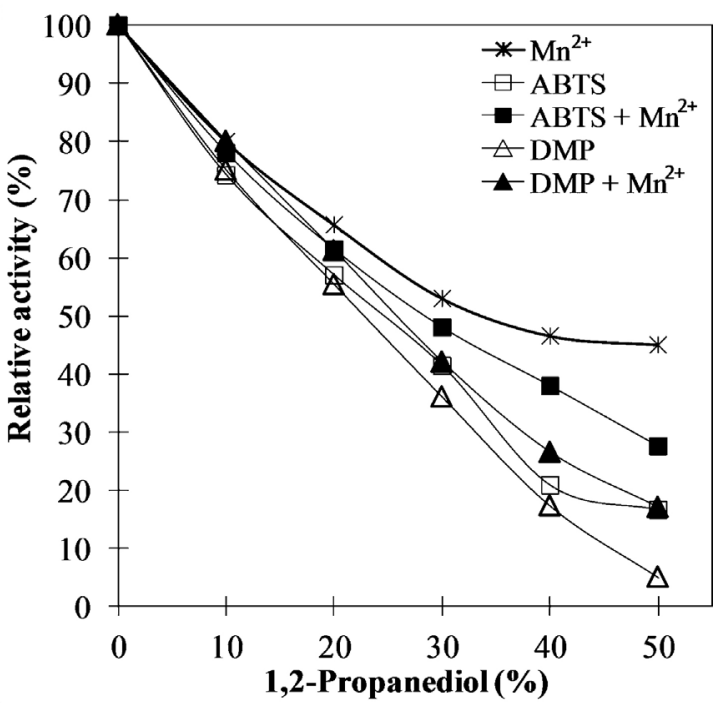

b)

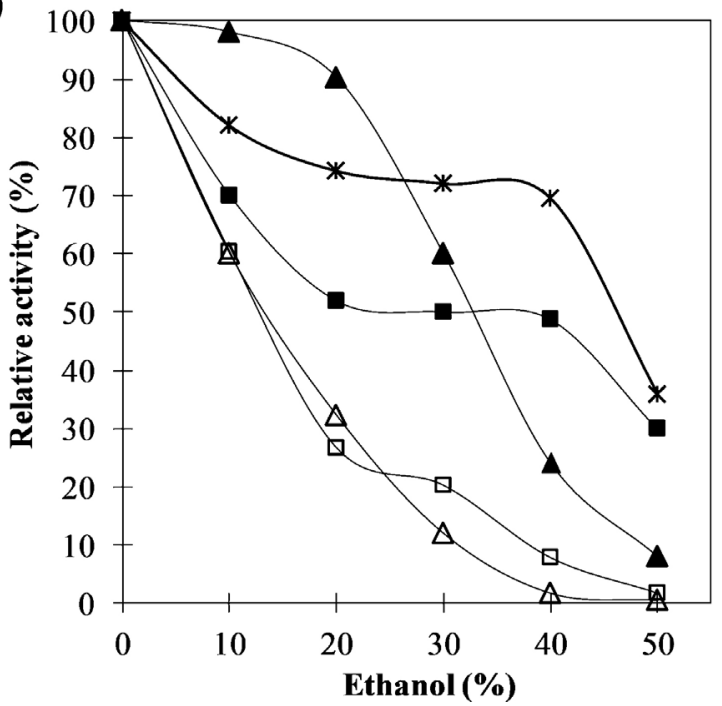

Fig. 3. Effect of (a) 1,2-propanediol and (b) ethanol on VP activity against three different substrates $\left(\mathrm{Mn}^{2+}\right.$, ABTS and DMP). ABTS and DMP reactions were followed in the presence and absence of $0.1 \mathrm{mM} \mathrm{Mn}^{2+}$. All reactions were initiated with $0.1 \mathrm{mM}$ $\mathrm{H}_{2} \mathrm{O}_{2} .100 \%$ corresponded to the enzymatic activity in the absence of those organic solvents, and values are expressed as the percentage of residual activity. Standard deviations from triplicates were less than $5 \%$ of the average value in all cases.

oxidation of DMP and ABTS, while the stabilizing effect indicates lower inhibition when the VP $\mathrm{Mn}^{2+}$-oxidation site is occupied by the ion during incubation with ethanol.

\subsection{Small molecules cross-linking by VP}

\subsubsection{Lignan cross-linking analysis}

Several parameters, such as the degree of polymerization (DP), the molecular mass (MM), and molar mass distribution (MMD) of the polymers enzymatically synthesized, should be analyzed to compare the efficiency of VP in lignans polymerization with that reported for other oxidative enzymes [34]. The polymerization of the substrates (DP and MM) was followed by MALDI-TOF MS. Control treatments, in the presence and absence of $\mathrm{Mn}^{2+}$, containing lignans and $\mathrm{H}_{2} \mathrm{O}_{2}$ but lacking enzyme were conducted to check for substrates self-polymerization, revealing the presence of dimers and trimers of lignans (Table 1 ). These non-enzymatic cross-links could arise from oxidation reactions, involving $\mathrm{O}_{2}$ or $\mathrm{H}_{2} \mathrm{O}_{2}$, mediated by traces of metal ions $[35,36]$. Despite of these unspecific links, the $\mathrm{VP} / \mathrm{H}_{2} \mathrm{O}_{2}$ system was capable of synthesizing molecules of much higher DP compared to the controls. Table 1 shows that most cross-linking occurred during the first $30 \mathrm{~min}$ of reaction and that the presence of $\mathrm{Mn}^{2+}$ enhanced the polymerization efficiency, raising both the reaction rate and the maximum DP of the products over the reaction time at all solvent concentrations. Table 2 depicts the predicted and experimental MM (accuracy $\leq \pm 1 \mathrm{Da}$ ) of the longest lignan homopolymers synthesized by VP, and the spectra of the reaction products are represented in Fig. 4. The assembly of lignan monomers is produced through an ether or carbon-carbon linkage that causes the elimination of two hydrogen atoms per cross-link [17]. The theoretical mass of the products can be calculated according to the equation $\left[n \mathrm{MM}-(\mathrm{n}-1) 2 \mathrm{H}+\mathrm{Na}^{+}\right]$, where $n$ is the number of monomers and MM is the molecular mass of lignan. The water-soluble SECO was the most efficiently polymerized substrate, forming nonamers and octamers in the presence and absence of $\mathrm{Mn}^{2+}$, respectively, after $24 \mathrm{~h}$ incubation. This value was similar or slightly higher than those reported for the crosslinking of SECO catalyzed by fungal [21] or bacterial laccases [37]. Over the first $2 \mathrm{~h}$ of reaction, polymerization of both SECO and HMR progressed at similar rates, but after $24 \mathrm{~h}$ the maximum DP of the later decreased in one unit while the SECO polymer reached its highest length (Table 1). Buchert et al. [20], reported the synthesis of HMR oligomers after $2 \mathrm{~h}$ incubation with a fungal laccase, but the products were 3-4 units smaller than those found in the present study at the same reaction time. Regarding 7-HSECO, the lignan dissolved in $50 \%$ ethanol, it is remarkable that the addition of $\mathrm{Mn}^{+2}$ produced two-fold larger oligomers as compared to the reaction without the cation, which could be due to an increased VP catalytic efficiency and stability, as described in the previous section.

SEC analysis of the VP-untreated and treated lignans, in the presence of $\mathrm{Mn}^{2+}$, showed the reduction of the low MM peak from the substrates along the incubation time, and a parallel increase of the $M_{w}$ of the products. Fig. 5 illustrates the MMD profiles of SECO and HMR, the two lignans that reached the highest DP. A single peak, corresponding to substrates, was observed after SEC of control samples without peroxidase. The appearance of oligomers along the reaction time is detected as new shoulders or peaks at the right of the substrates peak. The small increase in the low MM fraction from $24 \mathrm{~h}$ HMR reactions could be explained by the coexistence of polymerization and degradation activities in the reaction mixture, as previously reported for soluble-lignin samples treated with VP [38] and MnP [39]. This finding is in accordance with the fading of the signal from HMR octamers detected by MALDI-TOF analysis of this sample (Table 1). However, the global $\mathrm{M}_{\mathrm{W}}$ of the reaction components raised approximately $100 \mathrm{Da}$ from $2 \mathrm{~h}$ to $24 \mathrm{~h}$, suggesting that polymerization predominated over depolymerization during this period.

As in the case for all peroxidases, $\mathrm{H}_{2} \mathrm{O}_{2}$ is essential for VP activity and its eventual depletion stops the reaction. The effect of different $\mathrm{VP} / \mathrm{H}_{2} \mathrm{O}_{2}$ ratios on HMR cross-linking was assayed for $24 \mathrm{~h}$ treatments, either increasing 5 -fold the peroxide concentration or decreasing 10-fold VP dosage (from 1.5 to $0.15 \mathrm{U} \mathrm{mL}^{-1}$ ), and samples were analyzed at different reaction times. Enzyme-free controls demonstrated that HMR treatment with $0.5 \mathrm{mM} \mathrm{H}_{2} \mathrm{O}_{2}$ did not induce any additional polymerization. In contrast, HMR polymers only one DP larger in molecular size than those detected in low-peroxide reactions were detected in the VP dosed with 5fold more $\mathrm{H}_{2} \mathrm{O}_{2}$ system. The $\mathrm{M}_{\mathrm{w}}$ values increased around 200 and $300 \mathrm{Da}$ in $2 \mathrm{~h}$ and $24 \mathrm{~h}$-reactions, compared to the equivalent products obtained with $0.1 \mathrm{mM} \mathrm{H} \mathrm{H}_{2}$. SEC profiles (Fig. 5b) showed that the low MM peak decreased around 50\% in height, while a high-MM fraction of almost the same intensity appeared. Thus, higher doses of peroxide did not cause inhibition of VP, but rather improved its polymerization capacity. On the other hand, a reduced VP dosage resulted in the production of HMR oligomers of 5, 6 
Version définitive du manuscrit publiée dans / Final version of the manuscript published in :

Enzyme and Microbial Technology (2013), Vol. 52, №.6-7, p. 303-311, Dol: 10.1016/i.enzmictec.2013.03.010 Journal homepage: http://www.elsevier.com/locate/emt

Table 1

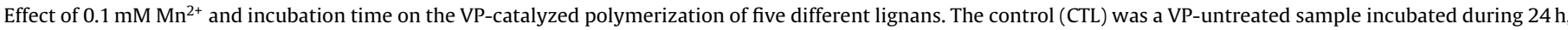

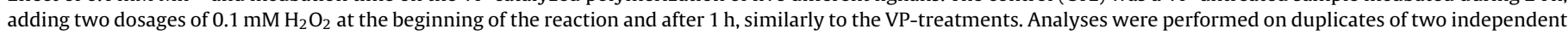
reactions, showing identical spectra.

\begin{tabular}{|c|c|c|c|c|c|c|c|c|c|}
\hline \multirow[t]{3}{*}{ Lignan } & \multirow[t]{3}{*}{ Solvent } & \multicolumn{8}{|c|}{ Maximal degree of polymerization ${ }^{\mathrm{a}}$} \\
\hline & & \multicolumn{4}{|c|}{$-\mathrm{Mn}^{2+}$} & \multicolumn{4}{|c|}{$+\mathrm{Mn}^{2+}$} \\
\hline & & CTL & $30 \mathrm{~min}$ & $2 \mathrm{~h}$ & $24 \mathrm{~h}$ & CTL & $30 \mathrm{~min}$ & $2 \mathrm{~h}$ & $24 \mathrm{~h}$ \\
\hline SECO & Buffer & 2 & 5 & 7 & 8 & 2 & 8 & 8 & 9 \\
\hline HMR & 20\% Ethanol & 3 & 5 & 7 & 6 & 3 & 8 & 8 & 7 \\
\hline MR & 20\% Ethanol & 2 & 4 & 5 & 5 & 2 & 5 & 6 & 7 \\
\hline CYCLO & 20\% Ethanol & 2 & 5 & 6 & 6 & 2 & 6 & 7 & 7 \\
\hline 7-HSECO & $50 \%$ Ethanol & 2 & 3 & 3 & 3 & 2 & 6 & 7 & 7 \\
\hline
\end{tabular}

a Values represent the maximum number of lignan units cross-linked as detected by MALDI-TOF MS.

and 7 monomers after $0.5,2$, and $24 \mathrm{~h}$, respectively, demonstrating that the amount of enzyme affected only the initial reaction rate, reaching the same DP values obtained at higher VP doses in $24 \mathrm{~h}$ (Table 1 ).

\subsubsection{Peptide cross-linking analysis}

The positive effect of $\mathrm{Mn}^{2+}$ in VP-catalyzed polymerization reactions has already been deduced from the previous experiments. Thus, the VP treatment of peptides, of different length and amino acid sequence, was performed in the presence of this cation. No peptide cross-linking occurred in the absence of VP or $\mathrm{H}_{2} \mathrm{O}_{2}$, as well as in peptides lacking tyrosine residues (Table 2) such as RKRSRKE and EPPGGSKVILF. In contrast, the $\mathrm{VP} / \mathrm{H}_{2} \mathrm{O}_{2}$ system was highly efficient polymerizing tyrosine-containing peptides, being as previously described for other oxido reductases [15,40,41]. Polypeptides were formed through the loss of two hydrogen atoms, probably due to the formation of dityrosine or isodityrosine bonds, resulting in monoisotopic masses whose theoretical value can be calculated according to the equation: $[n \mathrm{MM}-(\mathrm{n}-1) 2 \mathrm{H}]$, where $n$ is the number of monomers and MM is the molecular mass of each peptide. As an exception, the polymers from VEPIPY were detected as their sodium adduct. Table 2 shows the experimental and predicted MM from the highest DP molecules synthesized upon VP-treatment, and Fig. 4 depicts the spectra of the reaction products.
The peptide length and the position of tyrosine in the sequence had no effect on the DP of the products formed by the action of VP. This finding contrasts with the results obtained in similar reactions performed with HRP [41] or CiP [42], in which a strong effect of these two parameters on cross-linking has been reported. VP has several catalytic sites, one for (low efficiency) oxidation of phenols and dyes at the main heme access channel, a second one for $\mathrm{Mn}^{2+}$ oxidation at a (small) second heme access channel, and the third site for (high efficiency) oxidation of phenolic and nonphenolic aromatic substrates, located at the protein surface [11]. These features, which are not observed in other peroxidases (such as HRP) that only present the "classical" oxidation site at the main heme channel, can facilitate substrate oxidation even if the reactive moiety, such as the tyrosine, is placed in the middle of the sequence. Therefore, the cross-linking of tyrosine-containing peptides by HRP may be very restricted by steric hindrances and enzyme inhibition [41]. In contrast, VP can also oxidize its substrates at a second exposed catalytic site and via $\mathrm{Mn}^{2+}$ diffusion (Fig. 2), bypassing these problems.

In addition, VP-induced polymerization of peptides was very fast, reaching the maximum DP after $30 \mathrm{~min}$ in all cases. Regardless the reaction time, the predominant signals in most spectra corresponded to dimers, although tetramers and trimers were the main peaks detected after $2 \mathrm{~h}$ of reaction using GLY or VYV as the substrates, respectively (Fig. 4). The MMD of the products, derived from MALDI-TOF MS spectra, changed while the reaction proceeded due

Table 2

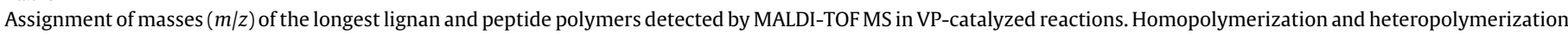

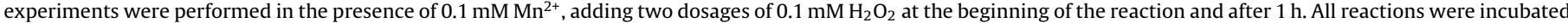
during $2 \mathrm{~h}$ excluding the homopolymerization of lignans which was carried out for $24 \mathrm{~h}$. $\mathrm{HMR}$ polymerization was accomplished with $0.5 \mathrm{mM} \mathrm{H}_{2} \mathrm{O}_{2}$ during $2 \mathrm{~h}$.

\begin{tabular}{|c|c|c|c|c|}
\hline Substrate & $\begin{array}{l}\text { Monomer } \\
\text { (Da) }\end{array}$ & $\mathrm{DP}^{\mathrm{a}}$ & $\begin{array}{l}\text { Predicted } m / z \\
\text { (Da) }\end{array}$ & $\begin{array}{l}\text { Experimental }{ }^{\mathrm{b}} \mathrm{m} / \mathrm{z} \\
(\mathrm{Da})\end{array}$ \\
\hline \multicolumn{5}{|c|}{ Homopolymers } \\
\hline \multicolumn{5}{|l|}{ Lignans } \\
\hline SECO & 362.1 & 9 & 3264.9 & $3264.1(-0.8)$ \\
\hline HMR & 374.1 & 9 & 3372.9 & $3372.8(-0.1)$ \\
\hline MR & 358.1 & 7 & 2516.7 & $2517.6(0.9)$ \\
\hline CYCLO & 360.1 & 7 & 2530.7 & $2531.5(0.8)$ \\
\hline 7-HSECO & 378.1 & 7 & 2656.7 & $2656.4(-0.3)$ \\
\hline \multicolumn{5}{|l|}{ Peptides } \\
\hline RKRSRKE & 959.1 & 1 & 959.1 & $959.6(0.5)$ \\
\hline EPPGGSKVILF & 1125.3 & 1 & 1125.3 & $1125.5(0.2)$ \\
\hline GLY & 351.4 & 8 & 2797.2 & $2796.9(-0.3)$ \\
\hline YST & 369.2 & 8 & 2939.0 & $2939.6(0.6)$ \\
\hline VYV & 379.5 & 11 & 4154.5 & $4155.0(0.5)$ \\
\hline YIGSR & 594.7 & 11 & 6521.7 & $6522.6(0.9)$ \\
\hline VEPIPY & 716.8 & 7 & 5027.6 & $5028.2(0.6)$ \\
\hline \multicolumn{5}{|c|}{ Heteropolymers } \\
\hline YIGSR/SECO & $594.7 / 362.1$ & $1 / 5$ & 2394.2 & $2393.7(-0.5)$ \\
\hline YIGSR/HMR & $594.7 / 374.1$ & $1 / 4$ & 2082.1 & $2082.6(0.5)$ \\
\hline
\end{tabular}

a $\mathrm{DP}=$ maximal degree of polymerization.

b The $m / z$ differences between the theoretical and the detected masses, shown in parentheses, are within the experimental error of the technique. 
Version définitive du manuscrit publiée dans / Final version of the manuscript published in :

Enzyme and Microbial Technology (2013), Vol. 52, №.6-7, p. 303-311, DOl: 10.1016/j.enzmictec.2013.03.010 Journal homepage: http://www.elsevier.com/locate/emt
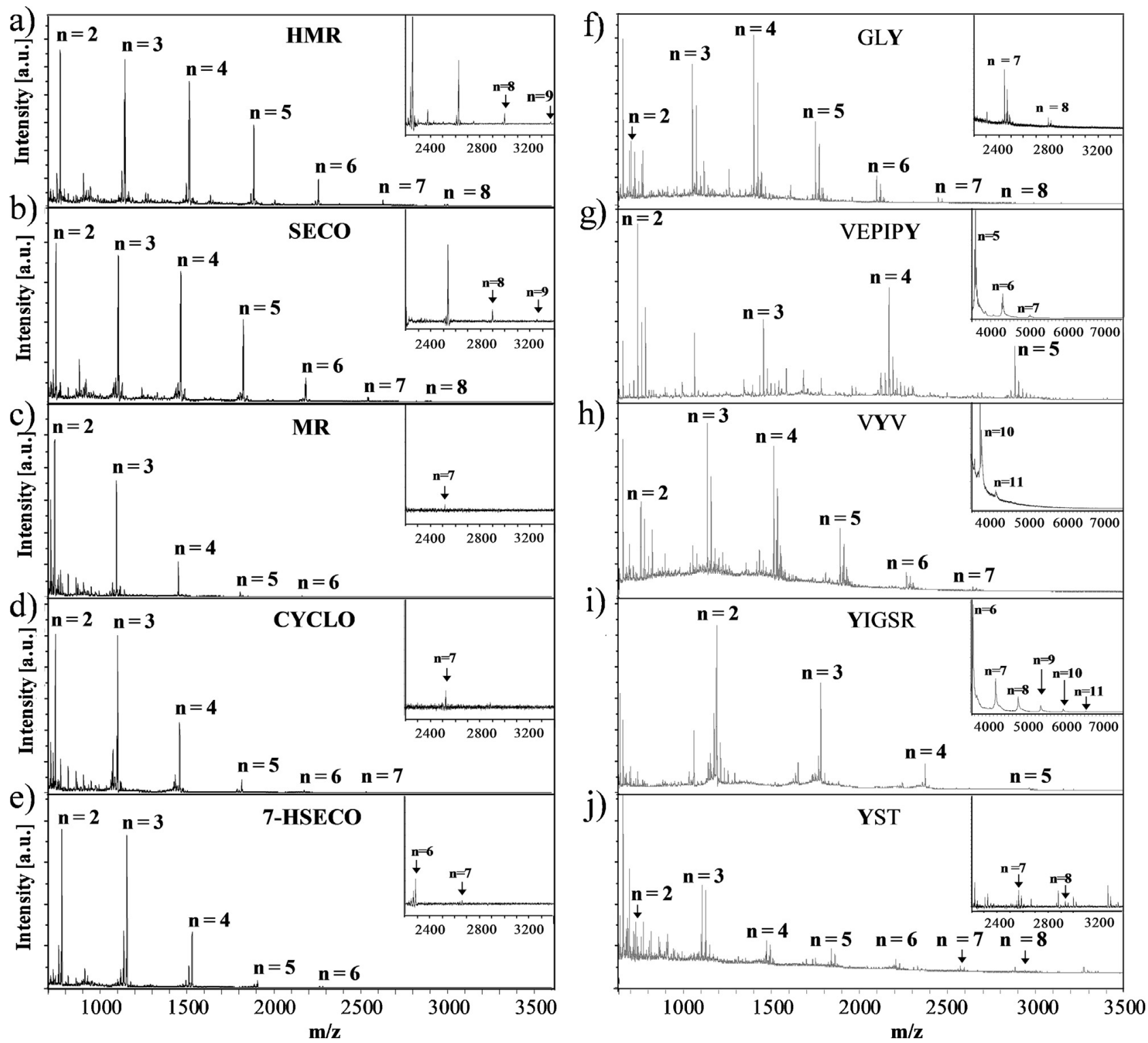

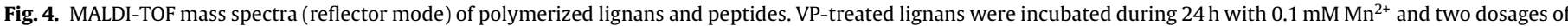

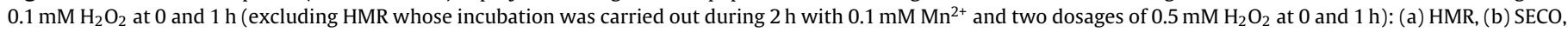

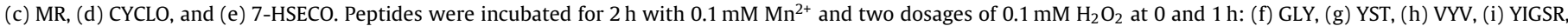

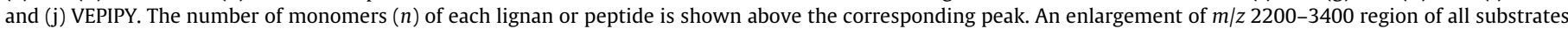

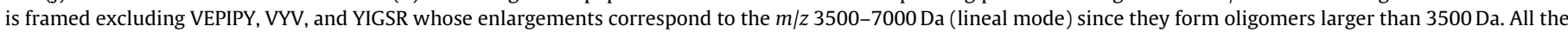
analyses were performed on duplicate (two independent reactions), showing identical spectra.

to the production of larger species. The production of pentamers of GLY, using a laccase from Trametes hirsuta [40] and hexamers of VYV with the C. cinerea peroxidase [15] in $24 \mathrm{~h}$, are poor values when compared to the nonamers of GLY and the undecamers of VYV obtained in VP-reactions of $30 \mathrm{~min}$ (Table 2). The results suggest that beyond a certain DP range, peptides polymerization is not favored under the reaction conditions used in this study or by other steric factors. Despite this limitation, our results show that, even at short reaction times, the polymerization degree was higher using VP, even though this enzyme has a more restricted activity compared to laccases, especially due to the low $\mathrm{H}_{2} \mathrm{O}_{2}$ concentration tested in this study.

\subsubsection{Heterogeneous cross-linking of lignans with peptides}

VP reactions containing SECO or HMR and each of the tyrosinecontaining peptides were incubated for $30 \mathrm{~min}$ and $2 \mathrm{~h}$ and analyzed to test the ability of the enzyme to catalyze the synthesis of heteropolymers. The MALDI-TOF spectra of the reaction products for each peptide-containing reaction showed that in most cases only lignan homopolymers were formed, detecting up to nonamers of SECO and octamers of HMR. Steffensen and co-workers [43] suggested that monolignols can have antioxidant effects, avoiding tyrosine oxidation in peptides when they are added to the reaction at the same concentration. Moreover, although the molar concentration of both substrates in the reaction mixture was the same and the MM of the tripeptides (GLY, VYV, YST) and the lignans is also similar, the later contain two-fold more reactive sites than the peptides (two phenols per one tyrosine, respectively). The probability for heterocomplex formation appears to increase with the number of reactive sites in the biopolymer. This proposition contrasts with the results obtained with VEPIPY. In this last case, and taking into account the gravimetric amount of the compound in the final reaction mixture, polymerization was not observed even though this peptide and the lignans contained a similar number of reactive sites. 
Version définitive du manuscrit publiée dans / Final version of the manuscript published in :

Enzyme and Microbial Technology (2013), Vol. 52, №.6-7, p. 303-311, DOl: 10.1016/j.enzmictec.2013.03.010

Journal homepage: http://www.elsevier.com/locate/emt

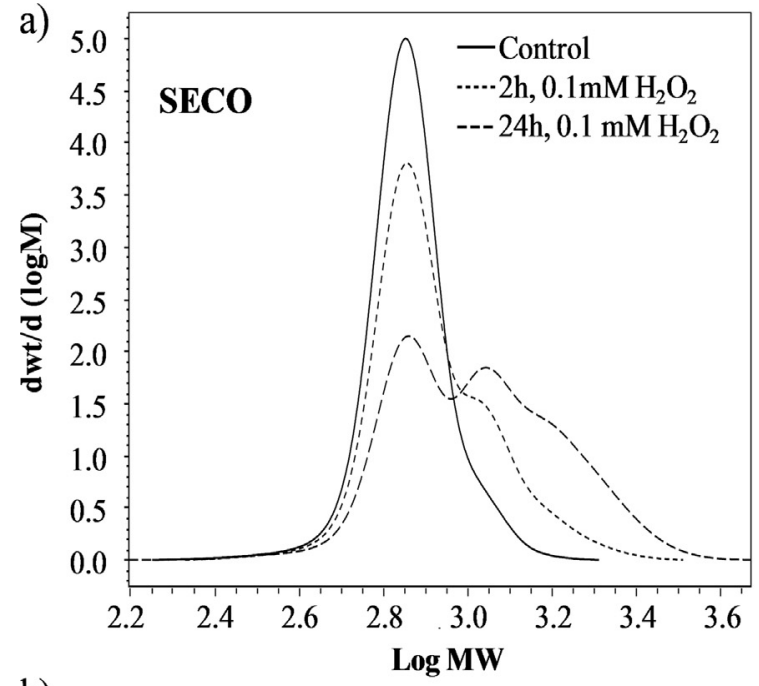

b)

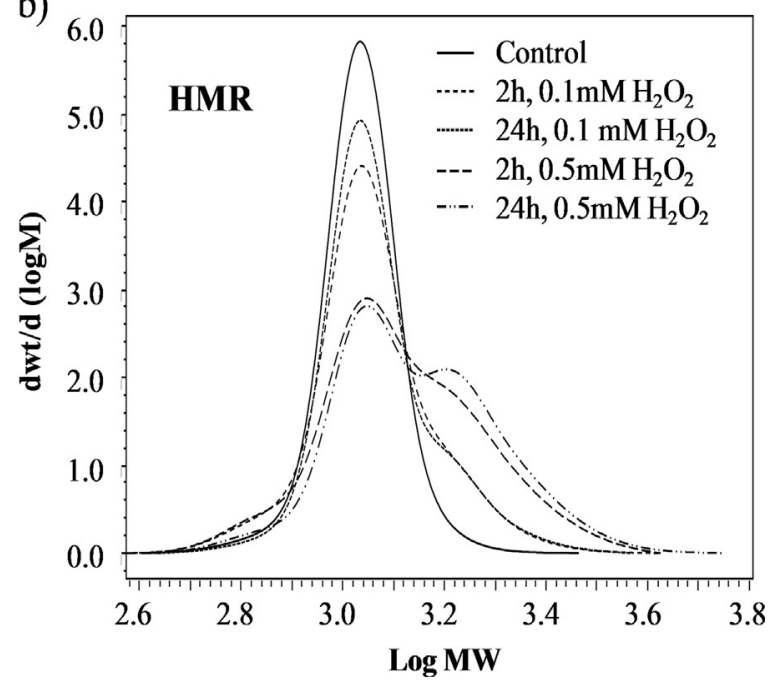

Fig. 5. Molar mass increase after VP treatment in the presence of $0.1 \mathrm{mM} \mathrm{Mn}^{2+}$ of: (a) SECO and (b) HMR. Controls correspond to VP-untreated SECO or HMR with $0.1 \mathrm{mM} \mathrm{H}_{2} \mathrm{O}_{2}$ at $24 \mathrm{~h}$ of incubation. Controls corresponding to VP-untreated HMR with $0.5 \mathrm{mM} \mathrm{H}_{2} \mathrm{O}_{2}$ were similar to the previous control and are not represented in (b).
Hetero-oligomers were only formed in reactions containing the peptide YIGSR with both lignans (Fig. 6), although lignan homooligomers were also detected. These heterogeneous cross-linking reactions took place through the elimination of two hydrogen atoms according to the equation: [nMM(YIGSR)+[nMM(lignan)$\left.(\mathrm{n}-1) 2 \mathrm{H}^{+}\right]-2 \mathrm{H}^{+}$. Peaks corresponding to peptide homo-oligomers were not found, contrasting with the high DP of the YIGSR units produced when incubated alone with VP (Table 2). YIGSR is a peptide derived from laminin and it is considered as an adhesive ligand, what can possibly facilitate its attachment and linking to other molecules [44]. These results indicate that, in the presence of both substrates, VP has a preference for lignans and if a heterocrosslinking occurs, only the lignan chain is further elongated.

\subsection{Large molecules cross-linking by VP}

\subsection{1. $\beta$-Casein cross-linking}

As VP was shown to efficiently cross-link small tyrosinecontaining peptides, the milk protein $\beta$-casein, consisting of 209 amino acids, four of which are tyrosines [45], was selected to determine if VP could cross-link larger proteins. The products were analyzed under dissociating and reducing conditions by SDS-PAGE, confirming that the complexes observed were due to the formation of covalent bonds and not by molecular aggregation. Large-size molecular species (approximately $150 \mathrm{kDa}$ ) appeared even at the lowest enzyme dosage and the band corresponding to the $\beta$-casein monomer slightly decreased over the reaction time, suggesting that a low percentage of protein was modified (Fig. 7, lane 6). In contrast, medium and high doses of VP resulted in an almost total fading of the $\beta$-casein monomer after $24 \mathrm{~h}$ (Fig. 7, lanes 7 and 10). Moreover, bands higher than $250 \mathrm{kDa}$ were observed at the top of the running gel, corresponding to polymers of at least 10-11 $\beta$-casein monomers. The polymerization of casein has been previously reported using HRP [18] and HRP plus ferulic acid [46] with similar results to those reported in the present study. Bands with a lower mass than $\beta$-casein appeared after long incubation times and in reactions with high VP doses. As previously discussed, the peroxidase can simultaneously catalyze polymerization and degradation at extended reaction times (Fig. 7, lanes 7-10). After $24 \mathrm{~h}$ of incubation, a slight aggregation was detected in all samples, which could be produced by the intra- and intermolecular transference of radicals formed from proteins during the reaction $[47,48]$. TEM images (Fig. 7) from water solutions of VP-treated casein allowed the observation of the protein as fibers, representing a typical

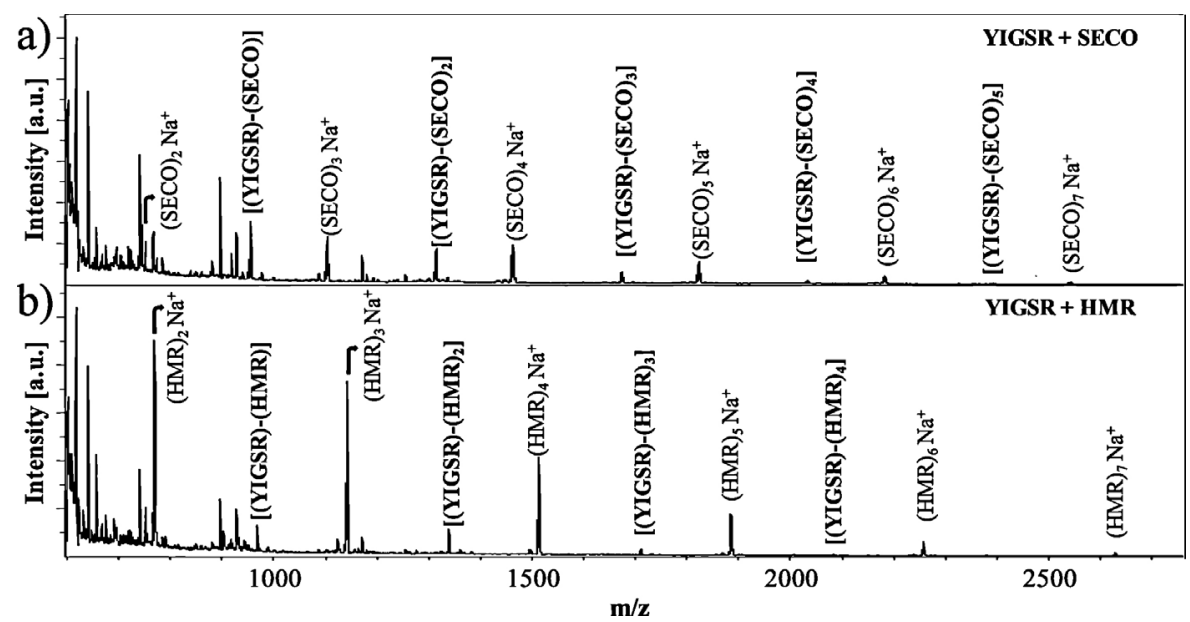

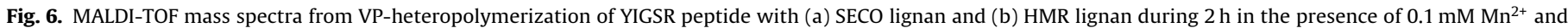

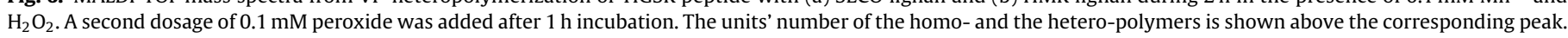
Analyses were performed on duplicates of two independent reactions, showing identical spectra. 
Version définitive du manuscrit publiée dans / Final version of the manuscript published in :

Enzyme and Microbial Technology (2013), Vol. 52, №.6-7, p. 303-311, DOI: 10.1016/j.enzmictec.2013.03.010 Journal homepage: http://www.elsevier.com/locate/emt

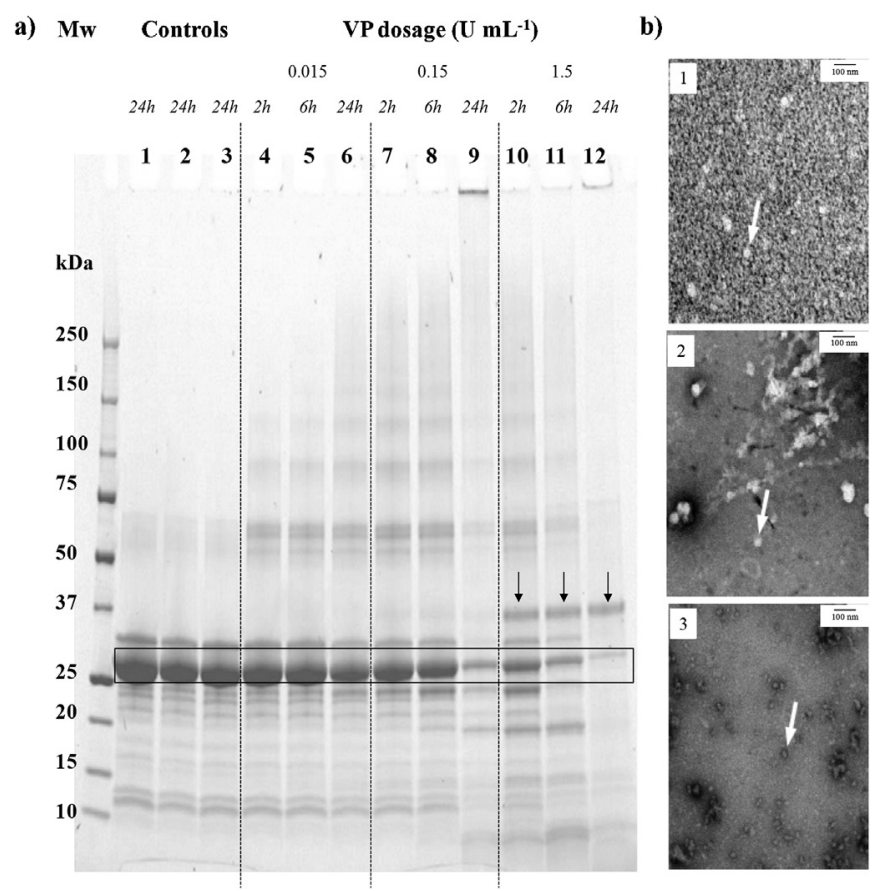

Fig. 7. Cross-linking of $\beta$-casein analyzed by SDS-PAGE and TEM. (a) SDS-PAGE of $\beta$-casein (Lane 1); $\beta$-casein plus $\mathrm{H}_{2} \mathrm{O}_{2}$ (Lane 2); $\beta$-casein plus VP (Lane 3); $\mathrm{VP} / \mathrm{H}_{2} \mathrm{O}_{2}$ treated $\beta$-casein with $0.015 \mathrm{U} \mathrm{mL}^{-1}$ of $\mathrm{VP}$ (Lanes $4-6$ ); $\mathrm{VP} / \mathrm{H}_{2} \mathrm{O}_{2}$-treated $\beta$-casein with $0.15 \mathrm{U} \mathrm{mL}^{-1}$ (Lanes 7-9); $\mathrm{VP} / \mathrm{H}_{2} \mathrm{O}_{2}$-treated $\beta$-casein with $1.5 \mathrm{U} \mathrm{mL}^{-1}$ (Lanes $10-12)$. Arrows are signaling the VP band $(\sim 43 \mathrm{kDa})$. The $\beta$-casein monomer is framed along the gel. (b) TEM photomicrographs of untreated $\beta$-casein (1), and VP-treated $\beta$-casein during $24 \mathrm{~h}$ of incubation with an enzyme dosage of $1.5 \mathrm{U} \mathrm{mL}^{-1}$ dissolved in water (2) or in urea $6 \mathrm{M}$ (3). Arrows are signaling $\beta$-casein monomers.

product structure upon molecular aggregation [49]. When VPtreated $\beta$-casein was dissolved in urea to disrupt aggregates, polymers were observed as irregular and compact structures with a broad range of sizes.

\subsubsection{FAX cross-linking}

Small deformation oscillatory rheology was used to follow gel formation caused by the oxidative cross-linking of feruloylated arabinoxylan. Control treatments lacking VP or $\mathrm{H}_{2} \mathrm{O}_{2}$ did not produce gels during $4 \mathrm{~h}$ reactions, and the same result was obtained with the lowest VP dosage $\left(0.015 \mathrm{U} \mathrm{mL}^{-1}\right)$. Neither the use of $1.5 \mathrm{U} \mathrm{mL}^{-1}$ of VP was useful for this monitoring since it produced an immediate gelation after $\mathrm{H}_{2} \mathrm{O}_{2}$ addition. A dosage of $0.15 \mathrm{U} \mathrm{mL}^{-1} \mathrm{VP}$ was selected for further experiments. The profile obtained with $3 \%$ FAX fitted the typical kinetic behavior displayed in enzymatic systems containing laccases [50] or other peroxidases [16]. Fig. 8 shows an initial increase of both $G^{\prime}$ and $G^{\prime \prime}$ followed by a plateau region. That plateau reached $G^{\prime}$ values of around $90 \mathrm{~Pa}$ and $G^{\prime \prime}$ values of $0.5 \mathrm{~Pa}$ in 10 and $7 \mathrm{~min}$ respectively, indicating that the sample had gel-like properties. The final phase angle was very low (below 0.5 degrees), highlighting the high elasticity of the gel. The gelation point, calculated from the crossover point of $G^{\prime}$ and $G^{\prime \prime}$, took place in about $2 \mathrm{~min}$. Apart from the diferulic covalent bonds, non-covalent links between arabinoxylans might also occur [22,51] and therefore the measured rheological properties depend on the arabinoxylan structural characteristics and the ferulic acid concentration.

Gels were generated only in reactions with 0.15 and $1.5 \mathrm{U} \mathrm{mL}^{-1}$ $\mathrm{VP}$, reaching the swelling equilibrium between 4 and $6 \mathrm{~h}$, with swelling ratio values $(q)$ of $53.4 \pm 0.4$ and $65.4 \pm 1.1 \mathrm{~g}$ water $/ \mathrm{g}$ FAX, respectively. These values were higher than those reported in other enzyme-catalyzed FAX gelation studies [52]. The fast reaction rate achieved with VP could cause the trapping of uncrosslinked FAX molecules inside the gel structure. These molecules would expand

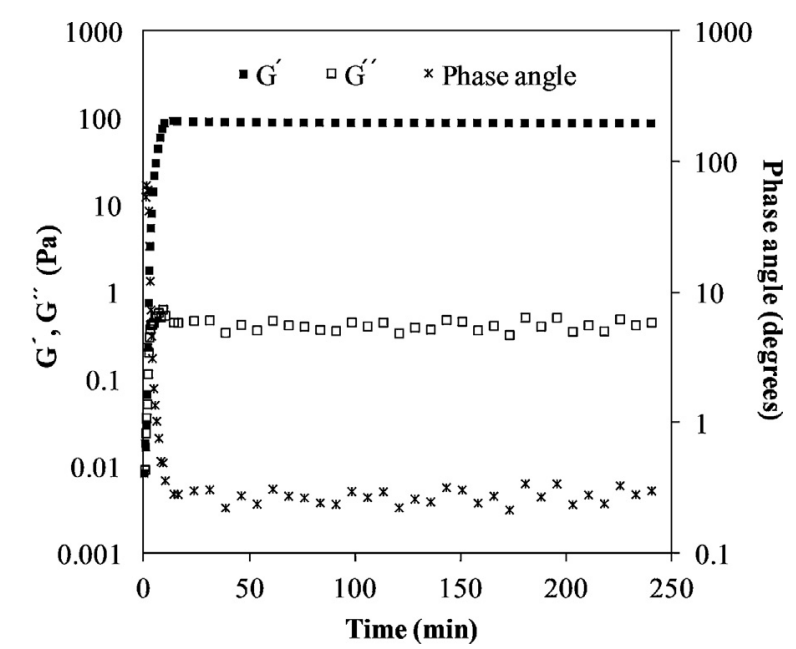

Fig. 8. The effects of VP-treatment on the rheological properties of FAX gels. Samples were analyzed in duplicate, showing coefficients of variation lower than $5 \%$.

quickly in contact with water, leading to its increased intake in the resultant FAX networks [16].

\section{Conclusions}

The modification by enzymatic cross-linking of biomolecules using the VP from $P$. eryngii has been achieved. The reaction conditions during VP treatments had a great influence in the reaction yields. In general, $\mathrm{Mn}^{2+}$ seemed to improve the VP stability and/or its catalytic efficiency even in the presence of organic co-solvents, which are essential in most reactions involving lignans. Only peptides containing tyrosine residues, regardless of their position in the sequence, are capable of forming a covalent bond through this kind of reactions, and heteropolymerization of lignans with a peptide resulted to be feasible. Moreover, VP-catalyzed cross-linking produced high mass macromolecules from $\beta$-casein and FAX. In view of these results, the application of VP for efficient polymerization of oxidizable compounds is suggested. Further screening of other potential substrates for VP and studies on the optimization of the polymerization reaction will be designed in the future. The P. eryngii VP used in this work is currently being subjected to structural-functional studies enabling rational design, as well as to directed molecular evolution, to improve its resistance to $\mathrm{pH}$ and $\mathrm{H}_{2} \mathrm{O}_{2}$, two important challenges for its application in biotechnological processes.

\section{Conflict of interest statement}

The authors declare that there are no conflicts of interest.

\section{Acknowledgements}

D. Salvachúa thanks the Spanish Ministry of Economy and Competitiveness for a FPU fellowship, P. Matikainen and B. Hillebrandt for technical assistance and Dr. K. Viljanen for the phenolic acids analysis (VTT, Espoo, Finland). We also thank Fernando Escolar for its help in TEM and J. Gil (CIB, Madrid, Spain). This work has been carried out with funding from the EU FP7 project "Peroxicats" (KBBE-2010-4-265397), the Spanish Ministry of Science and Innovation (BIO2009-08446, PRI-PIBAR-2011-1402), and the project "Lignin Fibre" financed by the Academy of Finland (Grant number 133091). 


\section{Journal homepage: http://www.elsevier.com/locate/emt}

\section{References}

[1] Kobayashi S, Uyama H, Kimura S. Enzymatic polymerization. Chemical Reviews 2001;101:3793-818.

[2] Walde P, Guo Z. Enzyme-catalyzed chemical structure-controlling template polymerization. Soft Matter 2011:7:316-31.

[3] Miletic N, Nastasovic A, Loos K. Immobilization of biocatalysts for enzymatic polymerizations: possibilities, advantages, applications. Bioresource Technology 2012;115:126-35.

[4] Hofrichter M, Ullrich R, Pecyna MJ, Liers C, Lundell T. New and classic families of secreted fungal heme peroxidases. Applied Microbiology and Biotechnology 2010;87:871-97.

[5] Floudas D, Binder M, Riley R, Barry K, Blanchette RA, Henrissat B, et al. The paleozoic origin of enzymatic lignin decomposition reconstructed from 31 fungal genomes. Science 2012;336:1715-9.

[6] Heinfling A, Ruiz-Dueñas FJ, Martínez MJ, Bergbauer M, Szewzyk U, Martínez AT. A study on reducing substrates of manganese-oxidizing peroxidases from Pleurotus eryngii and Bjerkandera adusta. FEBS Letters 1998;428:141-6.

[7] Banci L, Camarero S, Martínez AT, Martínez MJ, Pérez-Boada M, Pierattelli R, et al. NMR study of Mn(II) binding by the new versatile peroxidase from the white-rot fungus Pleurotus eryngii. Journal of Biological Inorganic Chemistry 2003;8:751-60

[8] Pérez-Boada M, Ruiz-Dueñas FJ, Pogni R, Basosi R, Choinowski T, Martínez $M J$, et al. Versatile peroxidase oxidation of high redox potential aromatic compounds: site-directed mutagenesis, spectroscopic and crystallographic investigations of three long-range electron transfer pathways. Journal of Molecular Biology 2005;354:385-402.

[9] Rodríguez E, Nuero O, Guillén F, Martínez AT, Martínez MJ. Degradation of phenolic and non-phenolic aromatic pollutants by four Pleurotus species: the role of laccase and versatile peroxidase. Soil Biology and Biochemistry 2004;36:909-16.

[10] Ruiz-Dueñas FJ, Martínez MJ, Martínez AT. Molecular characterization of a novel peroxidase isolated from the ligninolytic fungus Pleurotus eryngii. Molecular Microbiology 1999;31:223-36.

[11] Ruiz-Dueñas FJ, Morales M, García E, Miki Y, Martínez MJ, Martínez AT. Substrate oxidation sites in versatile peroxidase and other basidiomycete peroxidases. Journal of Experimental Botany 2009;60:441-52.

[12] Lú-Chau TA, Ruiz-Dueñas FJ, Camarero S, Feijoo G, Martínez MJ, Lema JM, et al. Effect of $\mathrm{pH}$ on the stability of Pleurotus eryngii versatile peroxidase during heterologous production in Emericella nidulans. Bioprocess and Biosystems Engineering 2004;26:287-93.

[13] García-Ruiz E, Gonzalez-Perez D, Ruiz-Dueñas FJ, Martinez AT, Alcalde M. Directed evolution of a temperature-, peroxide- and alkaline $\mathrm{pH}$-tolerant versatile peroxidase. Biochemical Journal 2012;441:487-98.

[14] Hamid M, Khalil uR. Potential applications of peroxidases. Food Chemistry 2009;115:1177-86.

[15] Steffensen CL, Mattinen ML, Andersen HJ, Kruus K, Buchert J, Nielsen JH. Cross-linking of tyrosine-containing peptides by hydrogen peroxide-activated Coprinus Cinereus peroxidase. European Food Research and Technology 2008;227:57-67.

[16] Martínez-López AL, Carvajal-Millan E, Lizardi-Mendoza J, López-Franco YL, Rascón-Chu A, Salas-Muñoz E, et al. The peroxidase $/ \mathrm{H}_{2} \mathrm{O}_{2}$ system as a free radical-generating agent for gelling maize bran arabinoxylans: rheological and structural properties. Molecules 2011;16:8410-8.

[17] Mattinen ML, Maijala P, Nousiainen P, Smeds A, Kontro J, Sipila J, et al. Oxidation of lignans and lignin model compounds by laccase in aqueous solvent systems. Journal of Molecular Catalysis B-Enzymatic 2011;72:122-9.

[18] Matheis G, Whitaker JR. Peroxidase-catalyzed cross linking of proteins. Journal of Protein Chemistry 1984;3:35-48.

[19] Saleem M, Kim HJ, Ali MS, Lee YS. An update on bioactive plant lignans. Natural Product Reports 2005;22:696-716.

[20] Buchert J, Mustranta A, Tamminen T, Spetz P, Holmbom B. Modification of spruce lignans with Trametes hirsuta laccase. Holzforschung 2002;56:579-84.

[21] Mattinen ML, Struijs K, Suortti T, Mattila I, Kruus K, Willför S, et al. Modification of lignans by Trametes hirsuta laccase. Bioresources 2009;4:482-96.

[22] Niño-Medina G, Carvajal-Millan E, Rascón-Chu A, Marquez-Escalante JA, Guerrero V, Salas-Muñoz E. Feruloylated arabinoxylans and arabinoxylan gels: structure, sources and applications. Phytochemstry Reviews 2010;9:111-20.

[23] Arihara K. Functional properties of bioactive peptides derived from meat proteins. In: Nollet LML, Toldrá F, editors. Advanced technologies for meat processing. Boca Raton, FL: CRC Press; 2006. p. 254-73.

[24] Stanic D, Monogioudi E, Dilek E, Radosavljevic J, Atanaskovic-Markovic $\mathrm{M}$, Vuckovic O, et al. Digestibility and allergenicity assessment of enzymatically crosslinked beta-casein. Molecular Nutrition and Food Research 2010;54:1273-84

[25] Boeriu C. Peroxidases in food industry: crosslinking of proteins and polysaccharides to impart novel functional properties. Romanian Biotechnological Letters 2008;13:81-6.

[26] Buchert J, Cura DE, Ma H, Gasparetti C, Monogioudi E, Faccio G, et al. Crosslinking food proteins for improved functionality. Annual Review of Food Science and Technology 2010;1:113-38.

[27] Anderegg RJ, Rowe JW. Lignans, the major component of resin from Araucaria angustifolia knots. Holzforschung 1974;28:171.
[28] Eklund P, Sillanpää R, Sjöholm R. Synthetic transformation of hydroxymatairesinol from Norway spruce (Picea abies) to 7hydroxysecoisolariciresinol, (+)-lariciresinol and (+)-cyclolariciresinol. Journal of the Chemical Society Perkins Transactions 2002;1:1906-10.

[29] Smeds AI, Eklund PC, Sjöholm RE, Willför SM, Nishibe S, Deyama T, et al. Quantification of a broad spectrum of lignans in cereals, oilseeds, and nuts. Journal of Agricultural and Food Chemistry 2007;55:1337-46.

[30] Martínez MJ, Ruiz-Dueñas FJ, Guillén F, Martínez AT. Purification and catalytic properties of two manganese-peroxidase isoenzymes from Pleurotus eryngii. European Journal of Biochemistry 1996;237:424-32.

[31] Faulds CB, Pérez-Boada M, Martínez AT. Influence of organic co-solvents on the activity and substrate specificity of feruloyl esterases. Bioresource Technology 2011;102:4962-7.

[32] Rodakiewicz-Nowak J, Jarosz-Wilkolazka A, Luterek J. Catalytic activity of versatile peroxidase from Bjerkandera fumosa in aqueous solutions of watermiscible organic solvents. Applied Catalysis A:General 2006;308:56-61.

[33] Morales M, Mate MJ, Romero A, Martinez MJ, Martinez AT, Ruiz-Dueñas FJ. Two oxidation sites for low redox potential substrates: a directed mutagenesis, kinetic,and crystallographic study on Pleurotus eryngii versatile peroxidase. Journal of Biological Chemistry 2012;287:41053-67.

[34] Mattinen ML, Suortti T, Gosselink R, Argyropoulus DS, Evtuguin D, Suurnäkki $A$, et al. Polymerization of different lignins by laccase. Bioresources 2008;3:549-65.

[35] Eklund PC, Långvik OK, Wärnå JP, Salmi TO, Willför SM, Sjöholm RE. Chemical studies on antioxidant mechanisms and free radical scavenging properties of lignans. Organic and Biomolecular Chemistry 2005;3:3336-47.

[36] Gómez-Toribio V, Martínez AT, Martínez MJ, Guillén F. Oxidation of hydroquinones by the versatile ligninolytic peroxidase from Pleurotus eryngii: $\mathrm{H}_{2} \mathrm{O}_{2}$ generation and the influence of $\mathrm{Mn}^{2+}$. European Journal of Biochemistry 2001;268:4787-93.

[37] Moya R, Saastamoinen P, Hernandez M, Suurnäkki A, Arias E, Mattinen ML. Reactivity of bacterial and fungal laccases with lignin under alkaline conditions. Bioresource Technology 2011;102:10006-12.

[38] Moreira PR, Almeida-Vara E, Malcata FX, Duarte JC. Lignin transformation by a versatile peroxidase from a novel Bjerkandera sp strain. International Biodeterioration and Biodegradation 2007;59:234-8.

[39] Hofrichter M, Lundell T, Hatakka A. Conversion of milled pine wood by manganese peroxidase from Phlebia radiata. Applied and Environment Microbiology 2001:67:4588-93.

[40] Mattinen ML, Kruus K, Buchert J, Nielsen JH, Andersen HJ, Steffensen CL. Laccase-catalyzed polymerization of tyrosine-containing peptides. FEBS Journal 2005;272:3640-50.

[41] Michon T, Chenu M, Kellershon N, Desmadril M, Gueguen J. Horseradish peroxidase oxidation of tyrosine-containing peptides and their subsequent polymerization: A kinetic study. Biochemistry 1997;36:8504-13.

[42] Steffensen CL, Mattinen ML, Andersen HJ, Kruus K, Buchert J, Nielsen JH. Cross-linking of tyrosine-containing peptides by hydrogen peroxide-activated Coprinus cinereus peroxidase. European Food Research and Technology 2008;227:57-67.

[43] Steffensen CL, Stensballe A, Kidmose U, Degn PE, Andersen ML, Nielsen JH. Modifications of amino acids during ferulic acid-mediated, laccase-catalysed cross-linking of peptides. Free Radical Research 2009;43:1167-78.

[44] Zustiak SP, Durbal R, Leach JB. Influence of cell-adhesive peptide ligands on poly(ethylene glycol) hydrogel physical, mechanical and transport properties. Acta Biomaterialia 2010;6:3404-14.

[45] Monogioudi E, Creusot N, Kruus K, Gruppen H, Buchert J, Mattinen ML. Crosslinking of $\beta$-casein by Trichoderma reesei tyrosinase and Streptoverticillium mobaraense transglutaminase followed by SEC-MALLS. Food Hydrocolloids 2009;23:2008-15.

[46] Li J, Li T, Zhao X. Hydrogen peroxide and ferulic acid-mediated oxidative crosslinking of casein catalyzed by horseradish peroxidase and the impacts on emulsifying property and microstructure of acidified gel. African Journal of Biotechnology 2009;8:6993-9.

[47] Dauphas S, Mouhous-Riou N, Metro B, Mackie AR, Wilde PJ, Anton M, et al. The supramolecular organisation of +1 -casein: effect on interfacial properties. Food Hydrocolloids 2005;19:387-93.

[48] Monogioudi E, Permi P, Filpponen I, Lienemann M, Li B, Argyropoulos D, et al Protein analysis by P-31 NMR spectroscopy in ionic liquid: quantitative determination of enzymatically created cross-links. Journal of Agricultural and Food Chemistry 2011;59:1352-62.

[49] Werning ML, Corrales MA, Prieto A, Fernández de Palencia P, Navas J, López $P$. Heterologous expression of a position 2 -substituted (1-3)- $\beta$-D-glucan in Lactococcus lactis. Applied and Environment Microbiology 2008;74:5259-62.

[50] Carvajal-Millan E, Landillon V, Morel MH, Rouau X, Doublier JL, Micard V. Arabinoxylan gels: impact of the feruloylation degree on their structure and properties. Biomacromolecules 2005;6:309-17.

[51] Berlanga-Reyes CM, Carvajal-Millan E, Lizardi-Mendoza J, Islas-Rubio AR Rascón-Chu A. Enzymatic cross-linking of alkali extracted arabinoxylans: gel rheological and structural characteristics. International Journal of Molecular Sciences 2011;12:5853-61.

[52] Meyvis TKL, De Smedt SC, Demeester J, Hennink WE. Influence of the degradation mechanism of hydrogels on their elastic and swelling properties during degradation. Macromolecules 2000;33:4717-25. 